\title{
Podmiotowość lasu
}

\author{
Krystyna Najder-Stefaniak \\ Zakład Filozofii, Szkoła Główna Gospodarstwa Wiejskiego w Warszawie \\ ul. Nowoursynowska 166, 02-787 Warszawa \\ krystyna_najder_stefaniak@sggw.pl• ORCID 0000-0003-4777-4663
}

\section{Streszczenie}

Autorka znajduje uzasadnienie dla „praw lasu” w podmiotowym istnieniu ekosystemów. Pojęcie życia pomaga jej zrozumieć, na czym polega podmiotowość ekosystemów. Zauważa, że specyfiką życia jest twórcze trwanie, które łączy trzy wymiary czasu: przeszłosśc, teraźniejszość i przyszłość. Myślenie o zależnościach w schemacie relacji ekosystemowej pomaga zrozumieć, jak możliwe jest takie twórcze trwanie. Autorka korzysta z pojęcia podmiotu odpowiedzialności, które znajduje u Romana Ingardena w pracy O odpowiedzialności i jej podstawach ontycznych. Bycie podmiotem odpowiedzialności uzasadnia posiadanie praw, które pozwalają przyczyniać się do realizowania prawdy, dobra i piękna. Dzięki aktywności ekosystemu, jakim jest las, mogą być realizowane te trzy wartości uniwersalne.

\section{Slowa kluczowe}

ekosystem, podmiotowość, odpowiedzialność, podmiot odpowiedzialności

\section{Wprowadzenie}

Las jest ekosystemem. Pojęcie ekosystemu użyte zastało po raz pierwszy przez Arthura George'a Tansleya w rozprawie The Use and Abuse of Vegetational Concepts and Terms. Tansley rozumiał pod tym pojęciem system wzajemnych oddziaływań (Tansley 1935). Pojawiło się ono w ramach nauki, która miała badać stosunki zachodzące między organizmami i środowiskiem, w jakim przebiega ich życie (Dołęga 2001). Zaproponowane w 1866 r. przez Ernsta Haeckela i uściślone przez Stephena Alfreda Forbesa w 1895 r., rozumienie ekologii przetrwało do dziś (Dołęga 2001).

Etymologia słowa „ekosystem” inspiruje do łączenia wyobrażenia domu (gr. oikos, znaczy dom) z pojęciem systemu. Dom oznacza miejsce, które jest schronieniem i środowiskiem pomagającym stawać się. System jest pojęciem projektującym rozumienie relacji w układzie stanowiącym całość. Oznacza zbiór wzajemnie powiązanych elementów, wyodrębnionych z otoczenia ze względu na te powiązania. Stał się ważnym pojęciem $\mathrm{w}$ refleksji filozoficznej za sprawą urodzonego w 1901 r., austriackiego biologa i filozofa, Ludwiga von Bertalanffy'ego. Napisana przez niego w $1928 \mathrm{r}$. książka Kritische Theorie der Formbildung dała początek kinetycznej teorii systemów otwartych i ogólnej teorii systemów. Zaproponował on teorię systemów pozwalającą wyjaśnić strukturę żywego organizmu postrzeganego jako system systemów, w którym niższe warunkują wyższe, a każdy ma 
własne cechy i rządzące nim prawa. W tej teorii potrzebny okazał się wprowadzony przez twórcę nowoczesnej teorii systemów termin ekwifinalność. Termin ten oznacza podstawową właściwość każdego systemu otwartego, jakim są systemy żywe. Właściwość ta polega na tym, że - odmiennie niż w układach nieożywionych - stan końcowy układu bywa osiągany różnymi drogami przy różnych warunkach początkowych. W swojej filozofii przyrody Bertalanffy przyjmował teleologiczność natury. Przyjmował też mistycyzm w kwestiach poznania istoty natury. Był przekonany, że w różnych systemach, mniej i bardziej złożonych (fizycznych, biologicznych, psychologicznych, społecznych), obowiązują wspólne zasady funkcjonowania. Gdy Bertalanffy rozszerzył teorię systemu organicznego na ogólną teorię systemów (Bertalanffy 1977), zaproponowane przez niego rozumienie systemu mogło stać się nowym paradygmatem $\mathrm{w}$ nauce.

W koncepcji urodzonego 18 lat później niż Bertalanffy Mario Bunge’a, który dokonał ogromnego dzieła aksjomatyzacji teorii fizycznej, szczególnie mechaniki kwantowej, system wyznaczany jest przez zbiór, jaki tworzą jego części, jego otoczenie i jego struktury. Dla zrozumienia działania i zmian stanów systemu niezbędne jest w teorii Bunge'a pojęcie otoczenia (Bunge 1977, 1979) Zmodyfikował tę teorię polski logik i filozof Józef Maria Bocheński (Bocheński 1994). W jego teorii systemów elementy systemu są od siebie zależne przyczynowo. Odróżniał on systemy scentralizowane, gdzie wszystkie elementy zależą od jednego elementu centralnego, i systemy niescentralizowane, gdzie nie ma takiego wyróżnionego elementu i wszystkie elementy zależą od siebie nawzajem. Systemy są otwarte lub zamknięte ze względu na relację z otoczeniem. Przykładem systemu otwartego jest żywa komórka, a przykładem systemu zamkniętego system aksjomatyczny (Bocheński 1994: 239-246).

Koncepcję oryginalną i bardzo pomagającą zrozumieć specyfikę podmiotowości i odpowiedzialności w kontekście ekosystemów zaproponował Roman Ingarden. Wprowadził on do refleksji etycznej pojęcie „systemów względnie izolowanych". Było mu ono potrzebne do ontologicznego uzasadnienia odpowiedzialności, okazało się przydatne przy omawianiu warunków, jakie spełniać musi podmiot odpowiedzialności. Zdaniem Ingardena, warunkiem podstawowym bycia podmiotem odpowiedzialności jest posiadanie „w sobie centrum działania, które umożliwia [...] uchwycenie inicjatywy" (Ingarden 1972: 133). Podmiotem odpowiedzialności może być system jednocześnie otwarty na otoczenie i posiadający w swej budowie urządzenia obronne, aby nie przeszkadzano mu w działaniu (Ingarden 1972: 133). Pojęcie systemów względnie izolowanych pomaga myśleć o specyfice ekosystemów.

W złożeniu „ekosystem” pojęcia „dom” i "system” promieniują na siebie znaczeniami i w rezultacie dom postrzegamy jako ukonstytuowany z relacji, a system zaczynamy postrzegać jako „żyjące” miejsce, które staje się jakieś dzięki konstytuującym je żywym elementom i jednocześnie daje tym elementom możliwości zrealizowania ich bycia.

Podmiotowość ekosystemów pomaga zrozumieć pojęcie życia. Jego specyfiką jest twórcze trwanie. Takie trwanie łączy trzy wymiary czasu: przeszłość, teraźniejszość i przyszłość. Myślenie o zależnościach w schemacie relacji ekosystemowej pozwala zrozumieć, jak możliwe jest takie twórcze trwanie. Każda epoka ma swoje centralne pojęcie, które ogniskuje myślenie (Simmel 2007). Na przełomie wieku XIX i XX stało się nim pojęcie życia. Życie można rozumieć tak, jak proponowano na przełomie XIX i XX w., jako to, co jest demoniczne i w sposób nieświadomy twórcze, lub tak jak w XXI w. podkreślać, że jego specyfiką jest twórcze trwanie łączące trzy wymiary czasu. Myślenie o zależnościach w schemacie relacji ekosystemowej pomaga zrozumieć, jak możliwe jest takie twórcze trwanie. W myśleniu ekosystemowym żywe systemy zyskują wymiar podmiotowości.

Pojęcie podmiotu odpowiedzialności jako systemu względnie izolowanego, które znajdujemy u Romana Ingardena w jego 
poszukiwaniach ontycznej podstawy odpowiedzialności, można zastosować do badań dotyczących ekosystemów, w tym lasu. Taki podmiot kontaktuje się $\mathrm{z}$ otoczeniem, ale źródło aktywności ma w sobie. W przypadku lasu tym źródłem aktywności jest życie.

Można wyróżnić odpowiedzialność: prawną, moralną i etyczną. Ekosystemy są odpowiedzialne w tym trzecim rozumieniu odpowiedzialności. Bycie podmiotem odpowiedzialności uzasadnia posiadanie praw, które pozwalają przyczyniać się do realizowania wartości. Dzięki aktywności ekosystemu, jakim jest las, mogą być realizowane: Prawda, Dobro i Piękno.

\section{Pojęcie podmiotowości w schemacie relacji ekosystemowej}

Pozostając w ekosystemowym paradygmacie myślenia, możemy zaproponować takie pojęcie podmiotu, które pomaga uzasadnić odpowiedzialność i twórcze możliwości nie tylko człowieka, lecz także ekosystemów. W schemat relacji ekosystemowej, która nie sprowadza się do zewnętrznego stosunku dwóch zamkniętych bytów, lecz jest interakcją zachodzącą między dwoma układami otwartymi, z których każdy, będąc całością, stanowi zarazem część tej drugiej całości (Morin 1977: 46), wpisuje się podmiotowość jako uwikłana w różne systemy bycia, które współtworzy i dzięki którym może się realizować.

Pojęcie podmiotu przenosi akcent $\mathrm{z}$ istoty bytu na jego istnienie. W paradygmacie myślenia nowożytnego aktywny „podmiot” przeciwstawiono „przedmiotowi”, który postrzegano jako obiekt subiektywnej aktywności. W paradygmacie myślenia ekosystemowego podmiot rozumiany jako „źródło” aktywności ugruntowanej w określonym systemie bycia może decydować, w jaki sposób odpowiada na szanse i zagrożenia, jakich dostarcza mu otoczenie i - odpowiadając tworzy zarówno siebie, jak i otoczenie.

Gdy zrezygnujemy z nowożytnego myślenia antagonizującego podmiot i przedmiot, gdy relacje postrzegamy w schemacie relacji ekosystemowej, zauważamy współkonstytuowanie się podmiotu i jego otoczenia. Otoczenie ma wpływ na aktywność podmiotu. Podmiot wpływa na otoczenie, w którym pojawia się zawsze jakiś rezultat jego aktywności. Schemat relacji ekosystemowej pozwala zauważyć, że podmiot, wzbogacając otoczenie rezultatami swojej aktywności, w konsekwencji wzbogaca siebie. Podmiot i jego otoczenie tworzą otwarty system, z którym podmiot pozostaje w interakcji. Zarówno podmiot, jak i utworzony system są układami otwartymi, z których każdy - pozostając całością jest jednocześnie częścią tej drugiej całości. Częścią podmiotu jest więc jego otoczenie, podobnie jak on jest częścią otoczenia.

Fakt, że aktywność skutkuje nie tylko przedmiotami, lecz także ubogaceniem podmiotu, zauważali starożytni Grecy. Zwraca na to uwagę Michel Foucault w pracy pod tytułem Hermeneutyka podmiotu (Foucault 2001). Zajmując się w niej genealogią nowożytnego pojęcia podmiotu, zauważa, że pojęcie podmiotu nie zostało wprowadzone dopiero przez Kartezjusza. Pojęcie podmiotowości Foucault odczytuje w rozumianej jako źródło aktywności psyche, śledząc rozmowę Sokratesa z Alcybiadesem. Zdaniem Foucaulta w rozmowie pojawia się pytanie o niemającą jeszcze w Grecji nazwy podmiotowość (Foucault 2001: 39), którą Alcybiades nazywa duszą. Z kontekstu wynika, że tym razem nie chodzi o „duszę uwięzioną w ciele”, o jakiej czytamy w Fedonie, ani o uskrzydloną duszę z Fajdrosa. Dusza, o której rozmawiaja Alcybiades i Sokrates, posługuje się mową i ciałem, jest źródłem zachowań i postaw, organizuje relacje z innymi ludźmi i z samą sobą (Foucault 2001: 55-56). Tak rozumiana dusza może być związana $\mathrm{z}$ pojęciem odpowiedzialności.

Roman Ingarden w podmiocie znalazł ontologiczne uzasadnienie odpowiedzialności. Opisując specyfikę podmiotu odpowiedzialności, użył pojęcia systemu względnie izolowanego (Ingarden 1972: 133). W zaproponowanym przez Ingardena pojęciu, warunkiem bycia podmiotem odpowiedzialności jest posiadanie „W sobie centrum 
działania, które umożliwia [...] uchwycenie inicjatywy" (Ingarden 1972: 133). Podmiot odpowiedzialności jest otwarty na otoczenie, ale ma w sobie urządzenia obronne, aby nie przeszkadzano mu w działaniu. Zauważmy, że podobne cechy możemy dostrzec zarówno w "duszy”, o której rozmawiają Alcybiades i Sokrates, jak i w ekosystemach. Jeśli za filozofami starożytnej Grecji powiążemy życie z duszą, to w ekosystemach dostrzeżemy podmiotowość w znaczeniu zaproponowanym przez Ingardena. Jako żywe organizmy są one otwarte na kontakty z otoczeniem i jednocześnie „względnie izolowane", czyli mają wpływ na to, jak reagować na otoczenie. W pewnym sensie „odpowiadają", a nie odreagowują na szanse i zagrożenia, jakich dostarcza otoczenie. Jest to możliwe, ponieważ mają własne trwanie.

Foucoult dostrzega różnicę między starożytnym i nowożytnym rozumieniem podmiotu. Ta różnica jest jego zdaniem w relacji podmiotu do prawdy (Foucault 2001: 18) W tekstach greckich filozofów współbrzmią ze sobą dwa postulaty: postulat poznania i postulat troski o siebie, czyli troski o źródło zachowań i postaw, organizujące relacje z innymi ludźmi i z samą sobą. Platońska psyche poznaje prawdę i aktualizuje własne możliwości bycia. Pomaga jej w tym troska o siebie inspirująca do realizacji techniki istnienia łączącej perspektywę prawdy i dobra. Efektem jest „rozwój sztuki istnienia” (Foucault 1995: 601). Zauważmy, że taka dusza ma własną teraźniejszość. Dzięki temu może albo współbrzmieć, albo pozostawać w opozycji do bycia systemu, którego jest częścią. Nie grozi jej unicestwienie, gdy system się twórczo przekształci. Ponadto może zmienić się w taki sposób, że skutkiem będzie twórcza zmiana jej otoczenia.

Ekosystemy wydają się realizować postulat poznania i postulat troski o siebie. Jak dusza z koncepcji Platona odkrywają prawdę, by aktualizować własne możliwości bycia. Chodzi nie o dostępną poprzez pojęcia prawdę $\mathrm{w}$ znaczeniu aletheia, ale o prawdę w znaczeniu emet. O ich podmiotowości można mówić, inspirując się pojęciem, na które zwraca uwagę Foucault, analizując rozmowę Sokratesa z Alcybiadesem (Foucault 2001: 39). Podmiotowość ekosystemów oparta jest na spójności prawdy i dobra. Prawda, w znaczeniu emet, i dobro nie są statyczne, ale są powiązane ze sobą tak, że nawzajem się dookreślają. Dzieją się i ekosystem odkrywa je, „dialogując” sam ze sobą i z otoczeniem.

W myśleniu nowożytnym została rozbita, wpisująca się w nierozerwalność prawdy i dobra, spójność podmiotowości. Poza tym podmiotowość przeciwstawiona przedmiotowości zaczęła zamykać się sama w sobie, by nie zostać uprzedmiotowiona. W rezultacie pojawił się problem polegający na tym, że podmiot musi dokonać wyboru, podjąć decyzję, za którą nie stoi żadna racja chroniąca od przygodności. Przygodność wydaje się być konieczną konsekwencją zrezygnowania z uzasadniających bycie kontekstów. Nowożytne rozumienie odizolowanej podmiotowości nie jest w stanie pomóc wyjaśnić funkcjonowania ekosystemów. Przygodność nie pomaga wytłumaczyć twórczego trwania ekosystemów.

Richard Rorty szukał ratunku przed przygodnością w „solidarności”. Solidarność rozumiał jako akceptację „przygodnie” uformowanych obowiązków, proponowanych w ramach jakiegoś „my”. Miał świadomość, że absolutna przygodność jest groźna, ponieważ musi skutkować całkowitym zagubieniem się w opcji „wszystko wolno”. Pojęcie podmiotu usiłował pogodzić z postmodernistycznym akcentowaniem wartości różnicy. Postmodernistyczny podmiot jest skazany na specyficzną autokreację, która nie powinna skutkować trwałą postacią. Dostrzegamy to zarówno w rozumieniu podmiotowości przez Richarda Rortego jak i Jacques'a Derridę.

Rorty proponuje takie pojęcie podmiotu, w którym jest on konfiguracją ściśle jednostkowych, niepowtarzalnych uwarunkowań (Rorty 1991: 20). W koncepcji Rorty'ego nie ma trwania podmiotu. Podmiot staje się tylko teoretycznym odniesieniem dla aktywności podmiotowej. Cel takiej aktywności wpisuje się w postmodernistyczny świat 
przygodności i jest odwrotnością celu Platońskiej psyche, Podmiotowość Rorty'ego skazana jest na formowanie siebie, które nie ma pointy. W podobnej sytuacji jest podmiot Derridiański, który skazany jest na ciągłe poszukiwanie siebie. W koncepcji Derridy, podobnie jak u Rorty'ego, z podmiotu pozostaje aktywność podmiotowa, ale znika jego uprzedmiotowiona obecność. W rezultacie mamy brak skutków tak rozumianej podmiotowej aktywności, brak dopełnienia w postaci rezultatu, który by trwał, i żadna z tych koncepcji podmiotowości nie może mieć związku z odpowiedzialnością.

Postmodernistyczna podmiotowość dzieje się w czasie, w którym nie sposób uzasadnić trwania teraźniejszości będącej geometrycznym punktem na prostej, punktem między przeszłością, już nieistniejącą, i przyszłością, jeszcze nieistniejącą. Punktowy czas postmodernicznej autokreacji implikuje doraźność bycia. Taka doraźność nie jest cechą ekosystemów. W myśleniu ekosystemowym czas ma ciągłość i trzy wymiary: przeszłość, teraźniejszość i przyszłość. Podobnie ekosystem, który dzięki temu ma zdolność do twórczej transgresji. Jego elementy wzbogacają system i współtworzą otoczenie systemu, inspirując swoim byciem do trwania będącego odpowiedzią na ich bycie. Twórcze zmiany w systemie możliwe są, gdy przynajmniej niektóre jego elementy mają własną teraźniejszość.

Schemat relacji ekosystemowej implikuje skomplikowaną ontologię podmiotu. W tym schemacie relacji nie ma sensu obrona podmiotowości polegająca na zamykaniu jej $\mathrm{w}$ granicach tego, co zaktualizowane z potencjalności bycia. Warunkiem podmiotowości jest twórcza transgresja. Można przyjąć, że aktywność podmiotowa ekosystemu jest ukierunkowana na ekosystem, a jej skutkiem jest życie ekosystemu, który wchodząc w relacje z otoczeniem, ma wpływ na to, że w tym otoczeniu mogą dokonywać się zmiany, że otoczenie może żyć, odpowiadając na aktywność podmiotu. Ekosystem jest odpowiedzialny i za siebie, i za swoje otoczenie.

\section{Podmiotowość i odpowiedzialność}

Pojęcie jest zawsze jakimś projektem rozumienia rzeczy, zjawiska czy stanu, projektem uwikłanym w szerszy kontekst rozumienia rzeczywistości. Pojęcie odpowiedzialności, jakie możemy wpisać w paradygmat myślenia ekosystemowego, pomaga zrozumieć odpowiedzialność ekosystemów, ich sprawczość skutkującą kształtem własnym i otoczenia. Pomaga zauważyć prawie zapomniany związek odpowiedzialności z „odpowiedzią” i „odpowiedniością”. Słowo odpowiedzialność sugeruje związek z odpowiedzią. Inspiruje do przyjęcia założenia, że bycie odpowiedzialnym, to możliwość udzielenia poprzez działanie właściwej odpowiedzi na sytuację. Działanie odpowiedzialne możemy postrzegać jako będące właściwą odpowiedzią na oczekiwanie systemu, w jaki się wpisuje, lub jaki chce zainicjować. Model relacji ekosystemowej pozwala zrozumieć „sprawstwo” jako „inspirowanie" do odpowiedzi.

Przywykliśmy do rozliczania z bycia odpowiedzialnym i ta perspektywa rozliczania przesłania istotę odpowiedzialności, jej związek ze sprawstwem rezultatów aktywności. Te rezultaty pojawiają się bez względu na to, czy to zauważamy i jak je oceniamy. Wyróżniamy trzy rodzaje odpowiedzialności: prawną, moralną i etyczną. Odpowiedzialność prawna i odpowiedzialność moralna są do siebie podobne w tym, że są ex post. Obie mają związek z takimi pojęciami, jak: zobowiązanie, obowiązek, powinność. Obie akcentują podległość i możliwość bycia ukaranym. Zarówno w przypadku odpowiedzialności karnej, jak i odpowiedzialności moralnej kara jest efektem oceny czynu, a nie bezpośrednim jego skutkiem. Inne jest pojęcie nieuwarunkowanej oceną odpowiedzialności etycznej. Akcentuje ono wymiar wolności i sprawstwa. Od odpowiedzialności etycznej nie można uciec, wpływając na ocenę czynu, albo zatajając czyn lub jego skutki. Odpowiedzialność etyczna nie jest zapośredniczona w ocenie, dzieje się automatycznie. 
Wszystkie pojęcia odpowiedzialności są kojarzone ze sprawstwem dokonywanych w realnej rzeczywistości zmian. Wierzono, że zmiany mogą być powodowane nie tylko przez człowieka. Odpowiedzialnością za nie obarczano także bóstwa, zwierzęta i siły przyrody, przedmioty, a nawet symbole i zaklęcia. Siły przyrody zwykle personifikowano w postaci jakiegoś bóstwa. Herodot w Dziejach opisał, jak ukarano cieśninę Hellespont nazywaną dziś Dardanele. Tę cieśninę uznawano wtedy za bóstwo. Stwierdzono, że jest ona winna zniszczeniu przez burzę mostów, które były ważne dla króla Persów Kserksesa. Mosty, znajdujące się pomiędzy Europą i Azją, były potrzebne królowi do zdobycia Grecji. Kserkses uważając, że cieśnina jest odpowiedzialna za niezrealizowanie przez wojsko celu, jakim było zwycięstwo, zdecydował, że powinna być ukarana. Kara polegała na wymierzeniu jej 300 batów, napiętnowaniu rozpalonym żelazem i pozbawieniu wolności przez zatopienie w niej kajdan. Poza tym zabroniono składać jej ofiary (Herodot 2005: 509). Kara była tu związana z odpowiedzialnością ex post, nie była bezpośrednim skutkiem aktywności, lecz skutkiem wyroku.

Nie jest to przykład odpowiedzialności etycznej, w przypadku której nie ma miejsca na oceniającego czyn - jest skutek aktywności, który dzieje się automatycznie i ma określony wpływ i na podmiot, i na jego otoczenie. W znaczeniu odpowiedzialności etycznej być odpowiedzialnym, to być sprawcą pojawienia się skutku. Taka odpowiedzialność wpisuje się między aktywność i jej rezultat. Jeśli podmiot aktywności jest odpowiedzialny, to znaczy mądrze odpowiada na sytuację, to rezultat aktywności musi być dobry. W przypadku ekosystemów dobrym rezultatem ich aktywności jest życie.

Od przełomu XIX i XX w. pojęcie życia ogniskuje myślenie, tak jak w XVIII w. pojęcie rozumu, które podkreśla to, co ponadczasowe, a w XIX w. pojęcie rozwoju, które akcentuje nieustanne stawanie się i wzrost (Plessner 1975). Życie można postrzegać jako to, co demoniczne i w sposób nieświadomy twórcze, lub podkreślać, że jego specyfiką jest twórcza transgresja, trwanie łączące trzy wymiary czasu: przeszłość, teraźniejszość i przyszłość. Nie potrafimy jednoznacznie zinterpretować fenomenu życia. Jego złożoność i różnorodność wymagają wielowątkowego definiowania. Problemy $\mathrm{z}$ jednoznacznym zinterpretowaniem fenomenu życia inspirują do jego poetyckich opisów i stwierdzeń, że „jest zjawiskiem uwarunkowanym przez materię, niby tęcza na wodospadzie, niby płomień." (Mann 1998: 406). Zdaniem Helmutha Plessnera, filozofa z neokantowskiej szkoły badeńskiej, badanie fenomenu życia wymaga wypracowania odpowiedniej metody (Plessner 1975). Ta metoda powinna uwzględniać podwójne usytuowanie bytu ożywionego („wewnątrz siebie” i „naprzeciw siebie”) i w konsekwencji - dwuaspektowy sposób przejawiania się bytów ożywionych (Plessner 1975). Wskazówka Plessnera jest ważna także w odniesieniu do ekosystemów. Gdy chcemy zrozumieć ich podmiotowość, powinniśmy uwzględnić tę dwuaspektowość. Autor Die Stufen des Organischen. Einleiturg In die philosophische Antropologie zauważa też inny problem metodologiczny, związany z badaniem zjawiska życia. Dotyczy on konieczności uporania się ze skutkami tego, że każda „nauka, czy to przyrodnicza, czy humanistyczna, przeprowadza na swoim obiekcie szczególnego rodzaju redukcję [...], która znajduje oczywiste odzwierciedlenie w jej pojęciach" (Plessner 1975: 25). W rezultacie mamy „mielizny dualizmów” i konieczność uporania się z ograniczeniami nauk szczegółowych.

\section{Podmiotowość lasu uzasadnieniem dla jego praw}

W myśleniu ekosystemowym żywe systemy nie są postrzegane jak mechanizmy. Żywe systemy nie są skazane na automatyczną reakcję spowodowaną działaniem lub zachowaniem otoczenia. Mogą one odpowiadać na sytuację podmiotowo. W rezultacie do opisów żywych systemów potrzebny jest termin ekwifinalność. Termin ten oznacza, 
zdaniem Bertalanffy'ego, podstawową właściwość każdego systemu otwartego. Ekwifinalność polega na tym, że stan końcowy układu bywa osiągany różnymi drogami przy różnych warunkach początkowych. Jest też termin ekwipotencjalność. Oznacza on sytuację, gdy przyczyny pochodzące z jednego źródła mogą spowodować całkiem różne rezultaty. Oba te terminy możemy odnieść do ekosystemów, systemów otwartych na otoczenie i będących źródłem swojej aktywności.

Ludwig von Bertalanffy przyjmował teleologiczność systemów żywych. Wydaje się, że głównym celem tych systemów jest życie. Las jako ekosystem jest źródłem swojej aktywności, odpowiada jakimś sposobem bycia na szanse i zagrożenia, jakich dostarcza sytuacja i jest odpowiedzialny za rezultaty, jakie ten sposób bycia w danej sytuacji powoduje. Powinien mieć prawa pomagające mu dobrze odpowiadać na sytuację, czyli realizować swoją przyczynę celową. Jego przyczyną celową jest własne życie oraz życia systemów składających się na świat. Prawa są zawsze odpowiedzią na obowiązki, cele i zadania, w realizowaniu których mają pomagać.

By las mógł realizować swoją przyczynę celową, powinien przede wszystkim istnieć. Potrzebne jest mu prawo do życia. By mógł odpowiedzialnie reagować na sytuację, powinien mieć prawo do rozwijania własnej podmiotowości. By twórczo współistnieć $\mathrm{z}$ otoczeniem, powinien być wspierany w realizowaniu Prawdy, Dobra i Piękna. Te transcendentalia i wartości uniwersalne należy realizować, żeby trwało życie. Las powinien być wspierany w realizowaniu wartości partykularnych i wartości uniwersalnych. Wartości rozumiane jako różniące się od bytu, który posiada treść i istnienie, tym że posiadają treść i obowiązywalność, porządkują aktywność w systemach, ukierunkowując działania. Wartości partykularne są ważne i porządkujące tylko w danym systemie. Wartości uniwersalne są ważne dla trwania wszystkich systemów.
Wartości uniwersalne dają szansę na taki związek z rzeczywistością, który nie zamyka aktywności w określonym systemie bycia, nie ogranicza aktywności przez partykularne cele. Wartości uniwersalne stanowią punkt odniesienia, gdy trzeba twórczo przekroczyć uwarunkowania systemów bycia, w których realizujemy aktywność. Dzięki wartościom uniwersalnym las może „dialogować” z innymi ekosystemami i radzić sobie z konfliktami, jakie mogą pojawić się $\mathrm{w}$ relacjach z tymi ekosystemami. Dlatego może być $\mathrm{z}$ tymi systemami solidarny. Las powinien mieć prawa pozwalające przekraczać granice partykularnych korzyści i realizować wartości uniwersalne. Projektując relacje człowiek-las, powinniśmy korzystać ze schematu relacji ekosystemowej. Ten schemat relacji sprawia, że możemy zrozumieć udział ekosystemów składających się na las w ekosystemie, jakim jest las, i udział ekosystemu, jakim jest las w ekosystemach składających się na las. Podmiotowość lasu uwikłana jest zarówno w zależności ekosystemowe lasu, jak i w zależności ekosystemowe układów otwartych składających się na las. Poza tym las jest częścią otwartych układów, jakie tworzy, wchodząc w ekosystemowe relacje ze światem tworzonym przez człowieka.

\section{Bibliografia}

Bertalanffy L. von, 1984, Ogólna teoria systemów. Podstawy, rozwój, zastosowania, Warszawa.

Bocheński J.M., 1994, O systemie, Principia, t. VIII-IX.

Bunge M., 1977, Treatise on Basic Philosophy, vol. 3, Ontology I: the Furniture of the World, Dordrecht. Dołęga J.M., 2001, Z filozofii nauk ekologicznych, w: Ochrona środowiska społeczno-przyrodniczego w filozofii i teologii, red. J.M. Dołęga, J.W. Czartoszewski, A. Skowroński, Wydawnictwo UKSW, Warszawa.

Filek J. (red. nauk.), 2004, Filozofia odpowiedzialności XX wieku. Teksty źródłowe, Wyd. UJ, Kraków. Foucault M., 2001, L'hermeneutique du sujet, Paris. Foucault M., 1995, Historia seksualności, Warszawa. Herodot, 2005, Dzieje, Warszawa. 
Ingarden R., 1972, O odpowiedzialności i jej podstawach ontycznych, w: tenże, Ksiażeczka o człowieku, Kraków.

Morin E., 1977, Zaginiony paradygmat - natura ludzka, Warszawa.

Pseudo-Platon, 1973, Alkibiades1 i inne dialogi oraz Defilicje, Warszawa.

Plessner H., 1975, Die Stufen des Organischen. Einleiturg In die philosophische Antropologie, Walter de Gruyter, Berlin - NewYork.
Rorty R., 1991, Contingency, Irony and Solidarity, Cambridge.

Simmel G., 2007, Filozofia kultury. Wybór esejów, Kraków.

Tansley A.G., 1935, The Use and Abuse of Vegetational Concepts and Terms, Ecology, 16.

\section{The forest's subjectivity}

\section{Abstract}

The author finds justification for 'forest rights' in the subjective existence of ecosystems. The concept of life helps her to understand the subjectivity of ecosystems. She notes that the specificity of life is the creative duration that connects the three dimensions of time: past, present and future. Thinking about dependencies in the ecosystemrelation scheme helps to understand how it is possible to be so creative. The author uses the concept of the 'subject of responsibility', which is found in Roman Ingarden's work 'On Responsibility and its Ontical Foundations'. Being the subject of responsibility justifies having rights that allow you to contribute to the pursuit of TRUTH, GOOD and BEAUTY. Thanks to ecosystem activity, which is the forest itself, these three universal values can be realized.

\section{Keywords}

ecosystem, subjectivity, responsibility, subject of responsibility 